\title{
Article
}

\section{Technology and science in classroom and interview talk with Swiss lower secondary school students: a Marxist sociological approach}

\author{
Wolff-Michael Roth ${ }^{1}$
}

\begin{abstract}
In much of science education research, the content of talk tends to be attributed to the persons who produce the sound-words in a speech situation. A radically different, sociological perspective on language-in-use grounded in Marxism derives from the work of L. S. Vygotsky and the members of the circle around M. M. Bakhtin. Accordingly, each word belongs to speaker and recipient simultaneously. It represents collective consciousness and, therefore, shared ideology, which can no longer be attributed to the individual. The purpose of this study is to develop a sociological perspective on language in science education, a perspective in which language continuously changes. I articulate this position in the context of classroom and interview talk with 14-year-old Swiss non-academically streamed lower secondary students about technology and science. In this context, science classrooms and interviews are shown to be microcosms of Swiss (German) culture and society reproduced in and through the situated talk about science and technology.
\end{abstract}

Keywords Language - evolution - cultural history - individual development · microgenesis $\cdot$ speech genre $\cdot$ ideology $\cdot$ linguistic change

The word is in consciousness that which following L. Feuerbach is absolutely impossible for one person, but is possible for two. (Vygotskij 2005, p. 1018)

Language lives and historically develops precisely here, in concrete verbal intercourse, not in the abstract linguistic system of forms of language and not in the individual psyche of the speaker. (Vološinov 1930, p. 98, original emphasis)

Die Sprache spricht [Language speaks]. (Heidegger 1985, p. 10, original emphasis)

In educational research, the words an individual says, for example, a student during an interview following a unit on the applications of science and technology to everyday life, generally are attributed to this individual. The words tend to be taken as expressions of the contents of the mind or as expressions of the beliefs a person

1 W.-M. Roth

University of Victoria, Victoria, BC, V8W 3N4, Canada

email: wolffmichael.roth@gmail.com 
might have (Roth 2008b). For example, when asked about her relation to technology ("How would you [describe] your relationship with technology?"), Birgit - a 14year-old Swiss student attending the second of three grades of a non-academically oriented lower secondary school (Hauptschule) who will soon leave school and enter an apprenticeship situation - says:

02 B: When I get something into my hands, then I will look at it; and when it is useful, for example, to take apart a computer, when my father turns off the Internet, then it will be useful to me when I know how to turn it back on. These sorts of things, I find them interesting. But when I see an engine room or something, then I take a look, yea, it goes down, here up and over there it comes out. And so, I then find that pretty good, but why it works like this, then I don't really ... So, when it is of no use to me, I don't really care.

Researchers might then say that Birgit is interested in technology especially when it is useful to her to know about it. The interest in technology is attributed to her as much as any knowledge related to it: both exist in the form of representations or other constructed things within the individual. Such an approach, however, becomes questionable if we accept the introductory quotations. Vygotsky suggests that the word is absolutely impossible for one person, but is possible for two; Vološinov emphasizes that language lives in concrete verbal intercourse rather than in language as a system or in the individual psyche; and for Heidegger (1985), it is language itself that speaks so that "we leave speaking to language" (p. 10). Language, in these positions, therefore is a phenomenon that transcends the individual human being and, in so doing, transcends individual human psychology: it is an irreducible societal phenomenon that requires sociological study. The words that we may be tempted to ascribe to Birgit, following Vygotsky, no longer can be attributed to her but to the two people in the interview situation and to language more generally. In the excerpt, therefore, we observe the Swiss-German language at work more than the individual Birgit. She only realizes existing possibilities of language. From the perspective of Vološinov, the words of the excerpt reflect the concrete verbal intercourse - i.e., the interview situation - rather than the individual psyche of the speaker or, as some culture-oriented scholars might want to claim consistent with the Sapir-Whorf hypothesis, in language as a system, some (discipline-specific, capital D) Discourse (e.g., Gee 1990). Moreover, Vološinov suggests that language lives and historically develops in concrete verbal intercourse, that is, it lives precisely because it is spoken and it develops on historical timescales scales precisely because of its use in concrete exchange and communication. That is, even though one might be tempted to say that Birgit, being only a teenager, enters a system of language, Vološinov takes the position that it is precisely in such situations as the interview about science and technology that her Swiss-German mother tongue lives (exists) and cultural-historically evolves. Birgit does not merely appropriate a given language: It is in and through Birgit's mouth that (the Swiss) language lives and changes. 
If we take accept the introductory quotations of the three scholars, then there are serious consequences for the kind of analysis we can conduct and how we have to approach and deal with the words that are produced in science lessons or in (clinical) interviews with science- and technology-related topics. The sequential order of events that are associated with research on language that undergoes continuous, real development has been given in this way (Vološinov 1930): (a) initially, the soci(et)al relations evolve as a function of the cultural field; (b) this leads to the evolution of communication and verbal transaction evolve, associated with a concomitant evolution of speech genres that appear in verbal intercourse; and (c) finally language, conceived of as a semantically and syntactically structured system, changes. From this theoretical position, therefore, the words Birgit pronounces first of all reflect the concrete conditions of the situation: these are a function of the interview and the interviewer-interviewee relation. Within the interview, the words are constitutive moments: producing the relation as much as the content. Moreover, the words, which, in a strong sense, belong to Birgit, the interviewer, and the speech community more generally, belong to categories of speech genres in life, therefore reflecting Swiss-German cultural life and society generally and the situated ideological creation during the interview specifically. Finally, the words reflect an instant in the continuously changing life of (Swiss) German - but only in the imperfect, static, and falsifying (ideological) way that a photographic portrait reflects the life of the person it depicts.

The purpose of this study is to develop a sociological perspective on language in science education. I present analyses of classroom and interview talk with 14-yearold Swiss-German non-academically streamed, lower secondary school students about technology and science through the lens of the sociological approach to linguistics articulated by Vygotsky and within the Bakhtin circle. The students had completed brief 4-lesson units designed as introduction of technology to general education as an entry point into science, with a special attention to medical technologies thought to be more attractive to female students. In this paper, I describe and exemplify the three-leveled approach to the analysis of language-inuse that derives from such an approach to language.

\section{Technology as an entry to science}

\section{The research perspective}

For more than four decades, science educators have made the pitch to teach science through technology, technological design, and other technological activities that integrate science with technology, engineering, and mathematics (e.g., Pedretti and Nazir 2011). Technology and technological design apparently provide an excellent context not only for learning science but also for integrating science with other school subjects such as mathematics, language arts, and social studies (e.g., Benenson 2001). The question of technology frequently crops up in the science education literature together with the theme of socioscientific issues, which constitute contexts where students can bring to bear science concepts on real issues, 
develop their fluency with technology, and connect science to their lifeworlds more generally. A typical issue would be involving students in the question whether a great lakes city should build a new power plant (Rose and Barton 2012). Technological design activities are beneficial for student understanding because in the process of designing, artifact-transforming actions come to be intertwined with the transformation of the objectified raw materials and artifact, the designer collective, and the mediating tools enabling that transformation (Hwang and Roth 2004; Roth 2001). Together, these transformations lead to a co-evolution of material artifacts, student designers, and the tools they use. But even when students do not design artifacts, the fact that technology is pervasive in our everyday lives and the fact that students are familiar with many technological devices may suffice to assist them in connecting what they know with associated scientific principles (Dewey 1938/2008). Dewey recognized that technology generally and engineering specifically might constitute an ideal context for learning science because students encounter them in their everyday lives. Because of this pervasiveness of technology in everyday life, there exist already vernacular forms for talking about it and, therefore, starting points for students to develop further competencies for talking about technology and science.

The listed supporting functions of technology to the learning of science have not gone lost to the developers of science education standards, who, already more than a decade ago, had included as "Content Standard E" the recommendation that students "should develop (1) abilities of technological design and (2) understandings about science and technology" (NRC 1996, p. 190). The authors of that report suggest that the linkage between science and technology is important because "any presentation of science without developing an understanding of technology would portray an inaccurate picture of science" (p. 190). The report highlights particularly the medical field and environment where scientific progress and problems arising from science are interconnected. In the more recent Framework for K-12 Science Education (NRC 2012), the ties between science and technology (engineering) have been strengthened in the sense that the linkage has become a central organizing theme. This framework emphasizes the integrated nature of science and engineering knowledge and the close relationship between scientific inquiry and engineering design practices. Teaching science and engineering together are expected to allow students to appreciate to a greater extent than they do that engineering (technology) is not merely subservient to science but in fact influences science. The Swiss (German) endeavor Technik in der Allgemeinbildung (technology in general education) is a concrete instance where curriculum development and teacher education are intended to lead to increasing student interest in technological questions and problems. Interest is to be generated particularly in young women. In current society, there still is a considerable "technological gender gap," which makes it that young women historically have had less favorable attitudes towards, beliefs about, and skills in technology (Canada and Brusca 1992); and this gap persists to the present day (e.g., Ring 2008). The Swiss (German) endeavor to bring technology into general education, with its special focus on medical technology, has as one of its major goals the increase in interests in technology among young women. 
The didactical concept of technology in general education in the Canton of Zurich

In Switzerland where the data for the present study were collected, there is a recognition that technology had played a minor role in general education - both in the basic primary and secondary school (Volksschule) as well as in the academically oriented secondary schools (Gymnasium) - even though the acquisitions of technology influence and shape our everyday lives in many ways. The project Technik in der Allgemeinbildung (technology in general education) at the Zürcher Hochschulinstitut für Schulpädagogik und Fachdidaktik - bringing together the Eidgenössische Technische Hochschule (an engineering, science, technology, mathematics and management university) and the Pädagogische Hochschule (a university of education) - aims at better integrating technology in teacher education and into school curricula. Technology offers interconnections between science and other school subjects.

The curriculum Technik in der Allgemeinbildung aims at involving students in contemporary discussions of issues arising from technology and its relations to nature and society (ETH 2012). By means of specific questions, students are to be enabled to distinguish facts, claims, speculation, and opinions. Foundational knowledge and solid conceptual understandings are to give students the competencies to participate in discussions about current issues and, in this, further build a conceptual foundation for their understanding of science. The list of competencies to be acquired includes (a) safe use of technical instruments, (b) interest and curiosity for technical contents, (c) ability to frame questions, (d) ability to process information, (e) ability to evaluate information, (f) understanding technological connections and relations, (g) development of values and value systems, and (h) ability to act responsibly. The curricular contexts in which such competencies and abilities are to be developed include bionics, gen technology, climatology-related research, medical technology, and nanotechnology. The curriculum is premised on the idea that learning is enabled when it (a) arises from concrete actions, (b) emerges from students' prior understandings and competencies, (c) is related to practical experiences, (d) orients itself to problems that are maximally authentic, (e) allows learners' reflections upon their own learning and individual learning paths, (f) arises from joint engagement with others, and $(\mathrm{g})$ happens in situations of joint responsibility of all participants in the classroom community.

In the present instance, teachers and university personnel together designed specific units and tested these in the classrooms of participating teachers. The units developed in the project - including units on light-emitting diodes (LEDs), X-ray photography, computer aided tomography, endoscopy, microprocessors, GPS technology, and hydraulics - are made available to the public through an online portal (ETH 2012). The present study draws on data collected during the development, teaching, and evaluation of two of these units: X-ray photography and endoscopy.

Following each new unit, the university-based developer and researcher (A. Zeyer) conducted a whole-class discussion with the participating classes concerning 
engineering, technology, and science. These classroom discussions were videotaped (March and April 2007). In addition, the researcher (Zeyer) conducted individual, audiotaped interviews with 6-7 students from each participating class (June 2007). The 20+ students in each class attended the second of three grades in a nonacademically oriented lower secondary school (Sekundarschule), which corresponds to about grade 8 ( $\sim 14$ yrs). Most of the students were already in the process of looking for an apprenticeship opportunity that they would enter after grade 9 with parallel enrollment in vocational school.

\section{Concrete lesson example: how X-ray images are created}

One of the units focuses on X-ray images and their creation. Its goal is to allow students to (a) understand the principle of the electromagnetic spectrum and the relationship between X-rays and visible light, (b) understand the creation of X-ray images as the projection of shadows produced by X-rays, and (c) enact simple anatomical interpretations of X-ray images. The curriculum is planned to extend over 4 lessons of 45 minutes each, clustered into two double lessons. During a preparatory lesson, students are asked to write about experiences that they have had with X-ray images. They are also asked to bring to class their own X-ray images, which they could obtain from their family physician or pediatrician. To exemplify the planned curriculum, the lesson plan for the first 55 minutes is provided in Fig. 1. (The full lesson sequence is available at www.educ.ethz.ch/unt/um/ta/roe.)

\section{«««《« Insert Fig. 1 about here "»»»»»}

After teaching the introductory lesson, the authors of the curriculum (T. Müller, A. Zeyer) report that students did bring X-ray images to the class. They used the Xray image of one girl, who had already written a small essay on her experiences, talked about it to the class. There was a lot of classroom talk associated with this report. The teachers report that this constituted an ideal entry into the topic. Later, the students, working in groups of 2-3, got to experiment with light and prisms. During the whole-class discussion the idea of the spectrum was extended to parts on either side of the color spectrum that the students had observed. This was facilitated because students, through the vernacular, were already familiar with such terms as infrared and ultraviolet. The teachers and curriculum designers report that the transfer to X-rays as part of the spectrum invisible to the human eye could be gauged from the fact that a student spontaneously asked a relevant question: If Xrays are dangerous, and if X-rays are part of the same spectrum as is visible light, are light or rays from mobile phones not dangerous as well?

During the second lesson, students have opportunities to see representations of the entire electromagnetic spectrum that contextualizes with respect to each other nuclear radiation, X-rays, ultraviolet, the visible spectrum, infrared, and radio waves. They read and fill out worksheets on W. C. Röntgen, the physicist whose name is associated with the discovery of X-rays, so that in the German culture the latter are referred to as Röntgenstrahlen (literally Röntgen rays).

In the third lesson, the students build an "X-ray" apparatus: By means of an overhead projector, they shine light onto the bones from a skeleton and then draw the outlines of the shadow that is projected onto flipchart paper. To make the task 
realistic, the set up resembles that used in regular X-ray imaging, where a person stands in front of the photographic plate.

In the fourth and final lesson of this mini-unit, the students work with X-ray images (negatives). They then receive another worksheet requesting them to draw $\mathrm{X}$-ray images of inner organs. The whole class then returns to the real X-ray images that they had brought to the class. The unit is completed by a discussion about which of the original questions recorded have been answered and which new questions have arisen from the unit.

The designers and teachers of this particular unit report that students initially exhibited a lot of interest. Many students brought X-ray images of their own bodies to class and wrote compositions in which they told about the context that had led to the recording of these images. Although the lessons had been lively, subsequent interviews revealed that students were divided in their appreciation of the unit as a whole. Whereas male students tended to like the experiments that they conducted, their female counterparts appeared to be less enamored by them. Although the medical focus of the unit was intended to address the learning needs of the young women, it apparently had not quite achieved this goal according to the teachers/developers.

\section{A sociological approach to the nature of language}

The purpose of this study is to develop a sociological perspective on language in science education exemplified by materials from lessons and interviews with Swiss (German) non-academically streamed lower secondary students. In this section, I articulate the (Marxist) philosophy of language underpinning this study and describe the methodological implications that derive from this approach.

\section{Marxist philosophy of language as living phenomenon}

For Vygotsky (2005), relations with others in societally specific situations are the loci where new psychological functions first are encountered in the course of human development. The societal relation is co-extensive with the higher order psychological function: The former requires the latter, and the latter is possible only because of the former. One collection of the psychologist's work has been published in English under the title Mind in Society (Vygotsky 1978). In fact, Vygotsky's own position may best be expressed in the following aphorism, which I created to make explicit the mutually constitutive relation between societal relations and psychological functions: Mind is in society to the extent that society is in the mind.

In oral communication, the situation as a whole carries what is required for understanding. This is clearly evident by the difference between oral communication - characterized by abbreviation to the point that everything may be expressed in intonation or by pointing - and written communication (Vygotskij 2005). Written communication takes many more sentences then verbal exchange because it has to put into words what is given in situation in the course of oral communication: It constitutes a world of its own, a new form and instrument of 
thought, and a necessary precondition of science as objective human endeavor (e.g., Ricœur 2010). Thus, it has been noted that "written speech is the most verbose, precise, and most-developed form of speech" (Vygotskij 2005, p. 996). In this form, language provides everything that is produced, in oral speech, by means of intonation and immediate perception of the situation" (p. 996). When written language is not "verbose and precise," problems arise. In the context of technologymediated communication, the difference between oral and written communication frequently gives rise to miscommunication and hurt feelings, because writers of messages tend to forget that there is a lack of context, which, in contrast to the faceto-face oral communication, needs to be explicitly articulated and made available. Failure to do so leads to communicative breakdown.

From a social-psychological perspective, "dialogical speech in fact is the original form of speech" (Vygotskij 2005, p. 996). This derives from the fact that "speaking is first a means of social intercourse, a means of utterance and understanding" (p. 675, original emphasis). Indeed, social intercourse existed prior to language as arbitrary system for making present again situations and things that are absent. An infant will use a word in the presence of an object, but will not talk about the object in its absence using words or other means to make the object present again. It is precisely in the maintenance of social intercourse that new words and other expressions (e.g., iconic gestures, see Roth 2012) first arise. These words, if they deserve to be collected by this concept, are already shared even at the instant that they articulated for a first time: directed to and produced for the other, they are already presupposed to be intelligible on the part of the other. This is evident in the following account of how a new verb, now common in culture more generally, emerged for my wife Sylvie and me.

Just after the release of a beta version of Google, Sylvie and I, as often at the table, needed some information. I said, "Let's Google for it," making up a word as it often happens in our bilingual conversations. We both laughed, and then talked about the construction of the verb based on the same pattern as "to Xerox [something]." Later we found others using the name of the search engine as a verb. Now it is an entry in the Oxford English Dictionary. (Research notes)

This episode shows that words are spontaneously created and words are shared even when uttered for a first time so that there is no need for an "inventor" of a particular word or phrase. This phenomenon, central to the sociological approach to language, tends to get lost in the body of literature on how students evolve and learn to speak and write in and about science. It is important to understand that science students do not learn a dead language but, in speaking, continuously create science language, which changes because it is used. From an individualistic psychological perspective, this is a proposition difficult to accept. However, language is a societal phenomenon and needs to be understood through a societal lens. Language is generated in concrete speech activity, and thereby becomes a resource for speech activity (A. A. Leont'ev 1969). With its use, the shared nature of a word or other sign is inherently a shared word or sign in the service of moving the conversation or 
situation ahead. Language is generative not only reproducing itself in the mouths of speakers but also giving rise to itself in new forms: language is change and, therefore, hybridity itself (Roth 2008a). Thus, words, signs, or ideas may arise spontaneously in different places - which is why there are sometimes acrimonious court battles over who was the first designer or inventor of an artifact, process, or theory. It is only after words have been in the public domain for a while and experienced more widespread use that they tend to be taken up into the formal language, an uptake that is recognized by the inclusion into dictionaries.

For the members of the Bakhtin circle (including V. N. Vološinov and P. N. Medvedev), too, the evolution of language moves from situated speech to changes in speech genres and statements isolated from the immediate use to changes in language as an ordered system. This implies a specific methodological order for analyzing any language-in-use:

(1) The forms and types of verbal interaction in relation with their concrete conditions; (2) the forms of distinct statements, isolated speech acts, in close relation with the interaction where they constitute the elements, that is, the categories of speech genres in life and in ideological creation that lend themselves to a determination through the verbal interaction; (3) from there, an examination of the forms of language in their normal linguistic interpretation. (Vološinov 1930, p. 98)

Like Vygotsky, the members of the Bakhtin circle recognize that a word specifically and any statement more generally always is located between author and recipient. In the context of Bakhtin, the Russian vyskazyvanie (вызказывание) is often translated into English as "utterance," but, because Bakhtin uses it also to denote poems and novels, a more consistent dictionary sense that is also consistent with translations from Russian into other languages (e.g., German and French) is "statement" or "expression" (Ger. Äußerung, Fr. énonciation). What matters for understanding a conversation or novel or poem is not the "meaning" of a word to the individual but the function that the word has in organizing the interlocutor relation. A word begins its life as a command operating upon and changing the behavior of others before individuals use it to operate upon themselves (Vygotskij 2005). Thus, the "actual reality of language-speech is not the abstract system of linguistic forms, not the isolated monologic statement, and not the psychophysiological act of its realization, but the social event of verbal intercourse implemented in a statement or statements" (Vološinov 1930, p. 96-97). For these reasons, verbal intercourse cannot ever be understood, explained, and theorized outside of the concrete context in which it takes place, that is, outside of the soci(et)al relation that it co-constitutes (Bakhtin 1979). Saying not only leads to the content of talk (i.e., the Said) but also, and more importantly, produces, structures, organizes, and coordinates the cultural field, that is, the soci(et)al-material context and relations that are currently occurring. It may therefore not surprise if some scholars write about text not only producing content but also generating the context. The result is that "as a living socio-ideological entity, as contradictory 
opinion, language, for the individual consciousness, lies on the border between oneself and the other" (Bakhtin 1975, p. 106).

There is an irreducible relation between what Bakhtin calls repliques (Rus. replika [реплика]) that are tied to one another in pairs - "question-reply, assertion-objection, affirmation-agreement, offer-acceptance, order-execution, etc." (Bakhtin 1979, p. 250). The rapport within each paired set of repliques cannot be derived from and is impossible within language as a system but is a variant of, and derives from, the relation between interlocutors. Each replique within a pair i.e., question and answer, assertion and objection - "presupposes the other (with respect to the speaker) member of the verbal exchange" (p. 250), and thereby presupposes an exotopy (outsidedness) of one with respect to the other. Here, the term exotopy denotes the fact that each replique manifests characteristics of language as being from the other, the direct counterpart of the current speaker, and his/her individual language characteristics (e.g., style). No replique (expression, statement), therefore, can be assigned to an individual speaker but always already belongs to self and other simultaneously. This is precisely the same point at which postmodern philosophers of language arrive (e.g., Derrida 1996). Language is continuously in movement between the other, from whom it comes and to whom it returns, and the self: it is both mine and not-mine simultaneously, a continual métissage-in-the-making, embodying difference and heterogeneity (Roth 2008a). If language is an unfinished process-in-the-making, then we need to theorize it in a manner where it is a living process rather than a static thing that students appropriate and then use for their own intentions. It is precisely this living aspect that the current paper is designed to bring to the foreground.

Methodologically, this sociological position on language requires researchers attempting to understand a conversation to take a pair of corresponding repliques as an irreducible unit. In the context of such units, "description and naming are employed to deal with aspects and phases of action, without final attribution to 'elements' or other presumptive, detachable or independent 'entities,' 'essences,' or 'realities,' and without isolation of presumptively detachable 'relations from such detachable 'elements'" (Dewey and Bentley 1948/2008, p. 101-102). This unit plays the same role as value does for K. Marx with respect to use-value and exchangevalue, two mutually exclusive but mutually presupposing terms during an actual, concrete commodity exchange process. (The analogy is nearly perfect, as the Russian word značenie [значение], often translated as "meaning" but more accurately having the sense of "signification" also has the dictionary sense "value.") We can identify a statement in the role of a question within a conversation only when we know the corresponding replique; if the succeeding statement is a reply, then the preceding one is a question; if the succeeding one is a declaration of having been insulted, then the (same) preceding statement has to be taken as an insult.

\section{Implications for method of analysis}

In this study, I take serious the implications that derive from the work of Vygotsky and the Bakhtin circle, according to which any word or statement in an 
ongoing conversation has to be treated as belonging to speaker and recipient simultaneously. Each turn, in fact, is treated as a replique. (In conversation analysis, only the second turn is conceptualized as reply.) However, being exotopic, each replique also is different, a realization of heterogeneity, hybridity, bricolage, and métissage (Roth 2008a): it is produced by the vocal cords of one and registered in the ear of the other. I take pairs of repliques (e.g., question-reply, invitationrejection, or invitation-acceptance) as irreducible units, each presupposing and determining the other. Because each replique thereby comes to be part of two pairs, the continuity of talk is actively theorized. Thus, for example, the following pair of turns is one fundamental unit. That is, we cannot say what is meant or done in turn 39 apart from the relation to turn 40. In fact, the transcriber, naïve with respect to the questions at the heart of this paper, placed a question mark at the end of turn 39 thereby indicating the hearing of a question. There is nothing grammatical that suggests a question; the statement could be heard as such if the intonation was rising toward the end of the statement. In the present case, the statement can be heard as an invitation or initiation ( $\mathrm{I}>$ ) to say what the student (Franz) apparently had expressed to do: to contribute to the conversation by saying something. In speaking, the student not only says something but also accepts the invitation $(A>)$. Above all else, turn 40, therefore, is an acceptance of an invitation, and turn 39 on the part of the researcher (R) is an invitation because it is paired with an acceptance. (Simplified excerpt from Fragment 3 below.)

I> 39 R: Yea, you wanted to say something?

A> $40 \mathrm{~F}$ : Um. Like I find it really sad that one could really do something with simple things and yet that nothing has been done so far=

I also take each turn (replique) as the knot that links up two turn pairs because it is equally part of two consecutive turn pairs. Thus, turn 40 completes the pair 39 | 40 and opens the pair $40 \mid 41$, so that an appropriate representation in which brackets show the unit to be analyzed should be set in this way:

$$
\begin{aligned}
& {\left[\begin{array}{lll}
\text { I }>39 & \text { R: } & \text { Yea, you wanted to say something? } \\
\text { A }>40 & \text { F: } & \text { Um. Like I find it really sad that one could really do something with } \\
& \text { simple things and yet that nothing has been done so far= } \\
\text { I> } 41 & \text { R: } & =\text { Yea, but what do you think? }
\end{array}\right.}
\end{aligned}
$$

This intermeshing of turn pairs is a direct consequence of the sociological approach to linguistics, which takes into account the irreducible nature of social facts (Durkheim 1919). Irreducible here means that the fact cannot be explained by appealing to the intentions of individuals (as frequently found in sociolinguistically inspired research). The minimal units to be used in the analysis are social/societal i.e., they are transactional in opposition to interactional (Dewey and Bentley 2008). A conversation is one such fact. It cannot be reduced to the independent contributions of independent actors entering an interaction. The irreducible nature of conversation is well known and frequently experienced in situations of decisionmaking, where the outcomes may be very different from the sum total of positions 
that the members to the setting had when they came to the meeting. The turn pair belongs to both interlocutors; and so does each part of the turn pair, that is, each turn.

The two turns do more than just invite and accept to contribute to the conversation; they institute a relation between the speakers. It is this relation that constitutes the concrete conditions that has to become the point of departure for the analysis of talk. The soci(et)al relation takes primacy to speaking, even though the latter contributes to constituting the former. From the cultural-historical perspective taken in this study, there is a mutually constitutive relation between speech activity, here represented by a fragment, and the relations that contribute to realizing the societal activity we are witnessing - schooling (A. A. Leont'ev 1969), as realized by the concrete science lessons taught by a visiting university-based curriculum developer, teacher, and researcher. Outside of the concrete situation, the verbal communication cannot be understood or explained (Vološinov 1930). The structure of the relation is associated with the different forms of activity, whether it is related to schooling, interviewing, family life, business, or lunchtime at work: "The everyday genre is a part of the social milieu ... it is in complete contact with that milieu and is delimited and defined by it in all its internal moments" (p. 99).

In this study, the analytic object is Swiss-language-in-use and the forms of the transaction rituals it produces and in which it is reproduced. The settings involve 14-year-old Swiss students and both language and transaction rituals are typical for Swiss society and for this age group. In the analytic approach used here, it is illegitimate to draw on information other than what participants make available to each other-e.g., by means of language, gestures, prosody, body orientations, or positions - or on what any native to the culture can hear. The trustworthiness of the analysis, therefore, cannot be grounded in additional materials, in claims to the number of similar instances, or any other technology in the traditional methodological repertoire.

\section{Technology and science in classroom/interview talk with 14-year-old students and in Swiss (German) society/language}

The purpose of this study is to develop a sociological perspective on language in science education. I articulate and develop the implications of the presented sociological approach to language grounded in a Marxist philosophy of language in the context of classroom and interview talk with 14-year-old Swiss (German) nonacademically streamed lower secondary students about technology and science. To do so, my analyses follow the methodological order for studying the changes of language (Vološinov 1930): (a) I begin with an analysis of the forms and types of verbal transactions in the given cultural field - i.e., lesson and interviews on the topic of technology and science; (b) I then unpack the forms of statements and speech acts in relation to the social intercourse where the former constitute irreducible moments; and (c) I examine the recent changes in the Swiss-German language associated with certain concept-words that appear in the recorded conversations. Because I analyze turn pairs of conversation, and because each word 
is taken to be an irreducibly collective phenomenon (from the other, for the other, returning to the other), my analytic object is the Swiss-German language-in-use rather than an individual's conception, "meaning," or belief. I am concerned with a system of ideas, ideology, rather than contents and properties of individuals. In this way, my analysis gets at soci(et)al phenomena that cannot be reduced to individuals even though the latter are integral part of the soci(et)al situations that are analyzed here.

\section{The forms and types of verbal transaction in relation with their conditions}

In the sociological approach to linguistics that the Bakhtin circle articulated and defended (e.g., Bakhtin 1994; Vološinov 1930), language lives and is kept alive in concrete verbal intercourse that both constitutes and is constituted by the concrete conditions of societal activity and associated societally specific relations. This implies that language itself changes when students talk in class about science and technology - even though the changes may not be observable immediately. But it is only when we take this position that we can understand linguistic changes at the individual and cultural-historical levels more generally. This position is the same as that taken in cultural-historical approaches to psychology (e.g., Vygotskij 2005) and psycholinguistics (A. A. Leont'ev 1969/1971), where the situation is understood as shaping the sense of the word to the point that the word itself may be unimportant, because everything pertinent is communicated by extra-linguistic means (gesture, prosody).

Making an interview Sociolinguists and discursive psychologists tend to point out that interviews are the result of joint interviewer/interviewee productions (e.g., Mishler 1991). Although this view is self-evident to some, it is not taken into account in research that uses (clinical) interviews for getting at an individual's sciencerelated knowledge, conceptions, attitudes, motivations, or beliefs (e.g., Roth 2008b). In this section, I show that the interview participants do not have to talk about the interview to make it; rather, they make the interview context all the while talking about science and technology. The following interview fragment picks up where we had left off in the introductory example, when Birgit ended offering the statement not to care about a technology that is not of particular use. From the dialogical perspective of the Bakhtin group, to understand language, we need to look at it from the perspective of its functioning-in-situation, that is, through the lens of its uptake. In fact, we need to understand each articulation through its double function of completing one turn pair and opening up the next turn pair. Thus, the statement "So, when it is not of use to me, I don't really care" is the second part of an irreducible pair of statements to which the first part is "And so for me there is the question, 'How would you [describe] your relationship with technology?'” That is, we have an irreducible question | reply pair, where each part is what it is only because of all other parts and because of the whole. (Following Roth, 2005, I use the Sheffer stroke "|" to create dialectical units that manifest themselves in one or the other of the phenomena denoted to the left or right of the stroke.) There is not just a statement the content of which could be attributed to Birgit - she does not care about those 
aspects of technology for which she has no use. It is the (temporally, conceptually) second part of a pair, where the first part is a question because the second is a reply and the second is a reply because the first is a question.

In turn 04, the interviewer produces a replique to the replique that precedes it. It makes a statement about the application of what has preceded to the four lessons approaching science through technology that the interviewer previously has taught. Depending on the intonation, the second part of the replique can be heard as an invitation to comment or as a question. The transcriber heard a question, and, therefore, placed a question mark at the end. The turn pair $04 \mid 05$ realizes an invitation and acceptance to comment, here modifying the preceding qualitative assessment "not really useful" to "not ... that bad."

\section{Fragment 1}

03 B: So, when it is of no use to me, I don't really care.

I> $04 \mathrm{R}$ : Now it would be exciting to translate this to the situation of our four lessons. That is not really useful, or?

A> 05 B: I didn't find it that bad.

I> 06 R: Yea, anyway?

A> 07 B: Yea.

I> 08 R: Could you describe that a little bit?

A> 09 B: It just was a fun atmosphere. It was interesting to see, what it had to do with it all. There are quite a few areas that one does not think about.

I> 10 R: So tell me. For example?

A> $11 \mathrm{~B}$ : With the laser in this thing. Like I already knew that water reflects, but that it [laser beam of light] can continue below [the surface], I found that fascinating.

Vološinov suggests that the analysis begins by investigating the forms and types of verbal transaction - question | reply, invitation | acceptance, or invitation | rejection - in relation with their condition. That is, the analysis needs to take into account that the turn pairs make for the conditions all the while constituting some content. Thus, each turn pair in the fragment above all has as its primary function to produce the interview situation and, second, to produce the content of the interview. For example, turn 04, as a second part in a turn pair, and the preceding statement that is realized as a question (from the perspective of the conversation) do not just produce content of a question and content of a reply. The interview situation, as relation, itself is produced by means of the conversation; and the conversation is produced because this is an interview situation. In the context of the turn pair $04 \mid 05$, the turn 04 constitutes an invitation - and as invitation the turn does relational work rather than being about content.

We observe in Fragment 1 eight complete turn pairs. Across these eight pairs, there is a distribution of speakers to the positions in question-invitation | reply pairs: one individual (the interviewer, researcher) takes the first position, whereas the other individual (Birgit, student, interviewee) always takes the second position. Here we have a particular genre of conversations given by the different positions that the participants take in the linked chain of turn pairs. The predefined relation - 
the researcher has invited the teacher and students to participate in interviews and the latter have accepted - orients participants toward a particular conversational genre; and it is in and through the production of the genre that the participants produce the preordained interviewer | interviewee relation. Saying that the relation is preordained, however, does not guarantee that the speech activity will actually produce what was nevertheless agreed upon. For example, I am aware of at least one report where a think-aloud session of an experienced scientist conducted by an undergraduate student from the same science department turns into a tutoring session, where the latter teaches the former how to interpret a graph (Roth and Middleton 2006). Such a reversal is possible only if there is an openness of the event to change itself in and because of the conversation; the event is not (fully) predetermined by any prior arrangements (knowledge or information about participants, context, etc.). The change is produced endogenously, from within the talk. Thus, at every instant during the event it is possible that Birgit says something like "I don't feel like continuing this," which would likely bring about the end of the interview. Each turn therefore has the important function to keep the interview situation alive until it is formally brought to an end through the collective (i.e., sympractical) speech activity of the participants.

The genre not only fits the situation but also produces it. Talk first of all is a means of producing, reproducing, and transforming the type of relation before it can be thought of as "having" content and being "about" something. Although I do not have a "perfect" counter-example in the present database for showing how actions lead to the dissolution of the societal form of activity and the corresponding absence of science- and technology-related talk, there is one "interview" that is not very productive in terms of soliciting talk. Here, the initiations (interviewing researcher) are paired with simple, even monosyllabic second parts (Samira, student).

\section{Fragment 2}

I> 32 R: So Mario, for example, he takes such things apart. This you would not think about?

A> 33 S: What?

I2> 34 R: Yes, he told me that every now and then he takes apart a cellphone.

A2> 35 S: No, no, not.

I> 36 R: He wants to see what is inside and like. So this is not your kind of?

A> 37 S: No.

I> 38 R: Do you have an idea about what you want to be, in which direction you want to go?

A> 39 S: No, precisely not.

I> 40 R: Are you at a loss?

A> $41 \mathrm{~S}:$ Yes.

It is apparent that a conversation about science- and technology-related topics has a hard time to get off the ground precisely because the relation required for a topic to be sustained do not (yet) exist. The inter-view, understood as the exposition and seeing of ideas of the other (in addition to the seeing of one another), does not exist as a relation. This has the consequence that anyone taking such a soci(et)al 
situation as a means of finding out about and coming to understand the "conceptions," "beliefs," or "meanings" of science- and technology-related topic of a student would literally not be able to see inside Samira.

Making a lesson In the same way that interviews constitute particular kinds of social situations, school lessons are social situations to which participants orient all the while they produce them in and through their actions. Lessons do not just exist but, constituting a special kind of relation, are produced, in part, by means of language. But the cultural field, institutional and physical arrangements, contributes to the reproduction of particular patterns, speech genres, and school-specific division of labor. Thus, for example, the researcher-"teacher" takes up specific positions with respect to the students, with a specific orientation of "the pupils" toward the teacher (Fig. 2).

\section{««《«《 Insert Fig. 2 about here «»»»»»}

The following fragment begins at the end of a longer turn (which turns out to be for a 2-minute stretch), where the teaching researcher talks about post-ecological perspective, itself being a replique to a student comment that people only begin to act on environmental problems when it is "really almost too late," and that people first have to experience personally the melting of ice and the increase of water levels before they do something. While the teaching researcher is talking, a student (Sebastian) in the back of the room has raised his hand. In a sudden shift of topic, which effectively brings to an end the talk about the post-ecological perspective the researcher then says, "Yea, you wanted to say something" (turn 39) while stretching out his arm, palm turned slightly upward, as if handing something toward the person he thereby addresses, as reified in the student taking a turn at talk (turn 40). We observe an offer and acceptance to speak. The orientation of the teaching researcher (Zeyer) and those of the other students, who turn, exhibit attention, further articulated in the interjection "yea" (turn 40a), with which recipients tend to both acknowledge their attention and allow the speaker to continue, just as this happens in the present fragment (turn 40b).

\section{Fragment 3}

I> 39 R: Yea, you wanted to say something? ((Points to a student in the back of the class who has raised his hand, as in Fig. 2.))

A> 40 F: Um. ((Most students turn around, looking at the speaker.)) Like I find it really sad that one could really do something with simple things,=

a R: =yea=

b F: =and yet that nothing has been done so far=

I> $41 \mathrm{R}:=$ Yea, but what do you think?

A> 42 F: Like, for example with the Alps, they say, for example, if it were without cars ("autofrei"), then you would have to go up there with gondolas, instead of driving up by car.

a R: yea.

b F: Simply such things, really simple things.

43 R: I am getting to this, later. 
A> $44 \mathrm{G}$ : Like, I think, we knew about it for a long time, but nobody has done something about it.

45 R: It has been known for a long time, but nobody has done anything about it, exactly. ((Continues in a longer stretch of talk.))

The transcription shows that there is at work both a more familiar and less familiar genre simultaneously. On the one hand, selection and invitation of a next speaker, and initiation positions are distributed unevenly across participants. In this fragment alone, we observe three initiation | acceptance turn pairs $(39|40,41| 42$, and $43 \mid 44$ ), and in each case the teaching researcher occupies the I-position, whereas a "student" is taken the A-position. The first part of turn 43 also flags an asymmetry, because something to come is anticipated; and such turns flagging a future event typically falls on the "teacher." Thus, it is this turn taking relation that reproduces the difference to which the participants are oriented. On the other hand, the situation is also marked by the absence of a special turn sequence that tends to be the norm in many other science and technology classes (van Eijck and Roth 2011). This frequently observed turn sequence has three positions: initiationreply-evaluation, and teachers typically take the first and third positions, whereas students take the second (Lemke 1990). The absence of the evaluative turn and the apparent ignorance of the teacher about what the next replique might bring constitutes this classroom as a different form of event than what may be normally observed, where the production of statements consistent with a particular version of science and technology is continuously evaluated, legitimated, approved, or rejected.

The actual, science- and technology related content is enabled to arise because the relationship is established. There are many classrooms - e.g., those with severe "discipline" "problems" in U.S. inner-city or French suburban (Fr. cité) schools, where students might pull knives and attack teachers - where content talk is impossible because most of the talk is concerned with producing the order of the situation itself. In the present situation, "everyone plays by the rules," allowing the classroom talk about a post-ecological perspective to emerge. The issue is important because research in science and technology education seldom if ever addresses the fact that there are many classrooms in which talking science is made impossible because of the particular soci(et)al relations that exist and the particular genres, with differential participant roles, do not support productive - in the sense of leading to student learning of content matter - schooling events.

\section{Categories of speech genre and ideological creations}

In the (Marxist) sociological approach to language, it is only when a societal relation exists that ideological creations and speech genres that express particular forms of life are possible. Accordingly, the second methodological stage in this approach focuses on "the forms of distinct statements, isolated speech acts, in close relation with the transaction where they constitute the elements" (Vološinov 1930, p. 98). That is, researchers are asked to focus only in the second instance on the 
"categories of speech genres in life and in ideological creation that lend themselves to a determination through the verbal interaction" (p. 98). This does not mean that there has to be a temporal lag between re/producing a relation and talking ideology. In fact, whenever interviewer and interviewee, for example, meet for a first time, they simultaneously build the relation while talking the topic. (The relationship building actually begins with establishing research ethics-related issues leading up to the signing of a consent form, even though this part is part is not on record precisely because consent for recording has to be established first.) As seen in the preceding section, the failure to build a working relation and the failure to have a science- and technology-related conversation, where both interlocutors contribute, also occurs simultaneously. This aspect in the analysis is most closely related to the going concerns in students' (and teachers') "conceptions," "beliefs," or "interests."

Each word or statement situates itself between and bridges speaker and recipient (as a commodity in Marx's political economy situates itself between seller and buyer, therefore manifesting itself in the exchange as exchange-value and usevalue simultaneously). It is produced because its intelligibility is presupposed, exhibiting therefore the orientation of the speaker toward the recipient (nobody in his/her right mind would talk to a toddler about nuclear power stations or WWF). Properly speaking, therefore, statements do not belong to speakers. If at all, they are produced because the intended recipient is anticipated to find it intelligible. Attributing a particular "view," "belief," or "conception" of science or technology to a student is therefore inappropriate. Ideological creations inherently are collective in nature and have their origin in the societal nature of mind. In this section, two excerpts, one from the classroom talk and the other from the interviews, are used to exemplify how the conceptual content of topics is distributed across speakers and properly speaking is a feature of the conversation, an irreducible social phenomenon. Topics and speech genres constitute ideologies, that is, systems of ideas that are generated, reproduced, and transformed in concrete speech situations. The first of the two fragments derives from a lesson, focusing on nongovernmental organizations (NGOs) and their agendas as an ideological creation and topic; the second of the two fragment focuses on gender, and the reproduction of gender division and gender stereotypes during an interview.

When a relation exists or is made simultaneously, an extensive exchange of ideas within a conversation becomes possible. This results in a development of the topic and ideas at the level of the conversation. This topic and its maintenance is a soci(et)al fact, requiring a sociological rather than an individual-psychological theory and method. Each turn is a possibility because the words and statements are (presupposed to be) intelligible. This orientation towards intelligibility is itself part of the relation (a Hobbesian [tacit] social contract). In fact, my analysis focuses on this conversation, which unfolds (develops) precisely because talk about Greenpeace, NGOs, globalization, forms of energy, and World Wildlife Fund (WWF), is possible and intelligible at the very instant that a person speaks.

\section{Fragment 4}

12 R: So when somebody said “Greenpeace just doesn't have a clue," then it received a label "Greenpeace doesn't have a clue," a label that one calls 
the N-G-Os, that is, non-governmental organizations, "these are just romantics: such a label. And this repeated itself everywhere. And one could see, "So many of you are saying this repeatedly." And in this connection, there was the question, what is globalization and economic growth and things like that? "It is something good," you said. It is something necessary, we need it, said your colleagues. And therefore it is an illusion to stop it and to want to dream about a world that consists entirely of green meadows and beautiful forests with kind animals.

I> 13 Now you wanted to say something?

A> $14 \mathrm{C}$ : Now I find it is everywhere the same thing. First something has to happen before the relevant people in charge begin to think about it. Really, many people do not believe that it could turn out well, because they have not yet seen the implications. So, for example, if there were something with nuclear power stations, and there were alternative energy forms, then people would not really believe in it. Then one first has to think about how a nuclear power station, yea, somehow blows up before the next person thinks about it.

I> 15 R: Would you stand behind such statements ((points to the overhead projection in the front of the classroom)), or do you find them inappropriate?

A1>16 C: So, W-W-F and Greenpeace, I wouldn't say so. Because W-W-F and Greenpeace, they really are doing something. These are the best known, they like-

A2> 17 D: I also find it rather- like the statement "W-W-F and Greenpeace are dreamers," that I don't find at all. I mean, they really accomplished a lot.

I> 18 R: So you don't think- You said, such things cannot be done. One cannot just go on the street and block trucks. This is not in: this is done only by someone who doesn't realize that the economy is so important.

A1>19 E: Yea, I think the environment is more important than the economy. I mean, we allow ourselves to become extinct, if we continue like this.

A2> $20 \mathrm{H}$ : A lot of people said this: but only our grandchildren.

In this fragment of classroom talk, the teaching researcher says what he says explicitly or implicitly presupposing the intelligibility of the describing, questioning, and commenting functions of his talk. This is not a general intelligibility but the anticipated intelligibility of the talk for these students attending a non-academically streamed lower secondary school. Students, too, say what they say presupposing the intelligibility of the talk they produce. That is, it is not their talk, not their opinions. Each statement presupposes its own possibility and mutual intelligibility. As Heidegger writes in the introductory quotation, it is language that speaks. From this perspective, "it is not we, in effect, who dispose of the word; it is the word that disposes of us" (Romano 1998, p. 222). If there were an issue with the intelligibility of a word, statement, or series of statement then the conversation itself would make the problem a topic. As long as the conversation does not exhibit some constitutive part of itself as problematic, any statement is taken as unproblematic (at least for the moment being). What we observe in Fragment 4, therefore, is a playing out of an 
ideology: it is produced here, inherently reproducing existing and transforming future possibilities of talk about this topic (the position of NGOs). Several ways of understanding the positions and actions of WWF, Greenpeace, and like-minded folk are articulated here: They are dreamers (turn 12), people who recognize problems but do not do anything about it, the post-ecological position (turn 14), and agents that truly bring about change (turns 16,17$)$. These are not individual students' views or opinions; what we hear is a form of ideology, a system of ideas concerning the role and impact of non-governmental organizations in society. The very talk constitutes the phenomenon as a living one. The topic is current in Swiss society at the time of the recording (2007), and any stretch of talk reproduces the topic and therefore keeps it alive. The ideology disappears and becomes a historical fact only when there are no longer concrete speech situations in which this topic is taken up again. The associated language forms also disappear and die when they fall out of use.

Gender and gender-related differences with respect to various aspects of technology (e.g., interest, participation, and parents' or siblings' relation to) constituted a recurrent theme in the classroom conversations and interviews recorded for this study. Making a simple attribute of "views" to students would be a considerable mistake, for some aspects of the science and technology unit were specifically designed in the light of an ongoing scholarly discourse about women in science and technology. Sometimes the interviewer and teacher introduced gender as a conversational topic; at other times a student drew on gender to explicate levels of interest in technology. Gender often arose from the current topic of the talk, such as when Birgit talks about watching her father repairing cars, which led to talking about her interest in engines, whether a boy would more likely do what his father does, here, repairing engines. The very talk about gender differences with respect to technology reproduces the language in which gender differences are framed and, with it, the possibility of such differences as a soci(et)al phenomenon that can be talked about. Such gender talk would have been different in the 1950s or 1960s. Switzerland was the last country in Europe to give women the right to vote - which arrived in 1971, even though the parliament had had made it possible for women to vote in 1958.

Even before students talked about gender differences, the investigator already had initiated the talk about boys and girls and possible differences between them in their appreciation of technology and science. Even if Alicia had never talked about science- and technology-related gender differences, the very fact that this becomes the topic keeps alive such differences as a topic and the related language genres. However, everyday talk and the vernacular offer many ways of producing and explaining differences according to gender lines. Unlike conceptual change researchers (at least in part of the history of the field) interested in eradicating forms of talk, the present position recognizes that the genres and language cannot be eradicated because these are kept alive in situated exchanges whenever people speak. It is only when there are no longer conversations about gender that such talk and associated language disappears. In fact, there have been historical times when gender issues where not as salient as they are today. The very fact that researchers 
continue to do gender-related research keeps the associated language alive - and, therefore, the associated forms of life.

\section{Fragment 5}

102 R: You said a little while ago: Girls also have to be interested and the boys also. So not everything is interesting to girls. Now we would have to find out what it is that girls- You know, this is an important question, it is about the fact that there are many girls who could go into technical professions but don't.

I> a And therefore the question, what is it, is it technology itself that really doesn't interest girls or are there special aspects that girls can find interesting? These are important questions in this connection. I don't mind if you do not find anything, we are just reflecting here together.

A>103 A: Sometimes it is just a mind game.

I> 104 R: Now we get back to what you said about your brother and your father. If you were not in this club, do you feel you would be less interested in technology?

A>105 A: Not necessarily. One can be increasingly interested in such things without actually seeing it so.

106 R: Yea, right.

I> a So you feel that girls support each other in not finding technology interesting?

A>107 A: Yea, in some cases it is like this, because you do not want to disappoint the other or does not want to become an outsider. Because there is the fear that you could become an outsider when you do something wrong or want to talk about another topic.

I> 108 R: Could a girl become an outsider when she says, technology is okay?

A>109 A: Really a girl should give her opinion to her mate and she should not only do what her mates do, but have her own opinion.

I> 110 R: Do you feel that if you were to say things, like that you watch these movies with your father and that you find this interesting, do you feel that you would become an outsider among the girls?

A>111 A: Like you can give your opinion, like really one should give your opinion, because you don't know what she wants.

I> 112 R: So when a girl is interested in car engines, would she become an outsider?

A>113 A: Like the others- you don't know at all whether they react negatively or positively, but one has to respect the opinions of others.

In this exchange, the topic are the technology-related interests of Alicia specifically and of girls generally and the relation of a girl interested in technology to her peers, that is, becoming an outsider in the peer culture that is not interested in technology to the same extent as other parts of Swiss society. The gender talk is mutually intelligible - in fact looking at the fragment as literary text, it would have been attributed to the author and his/her language. Just as words are inherently shared or remain unintelligible sounds, language enables topics to be talked about 
and understood. Because the phrase "Could a girl become an outsider when she says, 'Technology is okay"' presupposes that both interlocutors understand what it says and what the function of the phrase is (statement, question, order), its very production as cultural possibility is ascertained. That is, in this section I exemplify how categories of speech genres in life and in ideological creation are sustained in and through verbal transaction, itself constituted by and constituting the current form of activity (schooling, research interviewing). Given that interviewer and interviewees are of two different generations, these speech genres are therefore aspects of both. Interviews and classrooms constitute microcosms of Swiss (German) society and culture.

\section{Forms of (Swiss German) language}

(3) [F]rom there, an examination of the forms of language in their normal linguistic interpretation. (Vološinov 1930, p. 98)

Even in science classrooms, the emergence of new technology-related literacies has been observed (Roth 2007). But, being concerned with individual learners, science and technology education research rarely investigates the historical changes of language and literacy produced in classroom and interview talk. Language tends to be operationalized as a stable resource that research participants mobilize to express their ideas (from constructivist positions), as shaping the particular ways in which members to a setting can and do describe and experience events, or in terms of two stable languages that are hybridized into a third language (e.g., Moje et al. 2004). However, in the face of rapid changes of technology over the last several decades, languages are changing faster than ever; and this change means that we can literally observe that they are never self-identical (self-same). It is therefore not the case that two pure languages are hybridized into a third one, a process occurring in and constituting a third space. Rather, any language is a multiplicious hybrid: not merely a hybrid of two languages but a hybrid that has been hybridized a nearly infinite number of times (Roth 2008a). Even though little if at all discussed in the science- and technology-related educational literature, new nouns and verbs are continually created thereby changing what can be said, how phenomena can be described, and what becomes salient in educational experiences. Beginning with certain words that appeared in the recorded classroom videos and interviews, I conduct a historical analysis of words and associated phenomena. Even a surficial analysis would reveal that prior to a technology such as SMS, it would not have been possible as a topic or tool. Moreover, there is generativity at work, where new nouns (gender, case forms, singular vs. plural) and verbs (transitive vs. intransitive, weak vs. strong) with associated creations of grammatical forms are generated because required. With the arrival of new words, the frequencies of words in a language also change; and as do the kinds of things that we can perform with it (e.g., performing gender differences). But just as it takes a historical perspective of the evolution of hunting, guns, hunters, and rabbits to understand the killing of a rabbit today 
(Dewey and Bentley 1948/2008), the use and generation of words today takes a cultural-historical perspective.

From a cultural-historical perspective, phenomena such as language-in-use specifically and (changing forms of) activity more generally cannot be understood outside their historical context (A. N. Leont'ev 1983). To understand a stretch of talk, therefore, investigators are heeded to investigate science- and technologyrelated phenomena in their historical context, including in the changing context of the language that makes the particular forms of talk at an instant in history possible. Because science and technology educators tend to use language as a stable resource, they actually do not have a theoretical framework to capture the continuously changing nature of language - which occurs even as the participants speak about science and technology and thereby realize classroom and interview talk.

Given that the nature of the special lessons and the related interview talk concerned science and technology, it is not surprising that the transcriptions are filled with associated nouns and verbs that did not exist one or more decades ago, including "Natel" (a Swiss-German word for cell phone), "Handy" (German for cell phone), "Laptop [laptop]," "Klonen [cloning]," “computer," "video camera," "SMS" (Short Message Service, a text messaging service), "Solarmobil [solar vehicle]" "MP3-Player" (a player of sound recordings using the digital audio MP3 format), "Internet," “Game-Konsolen" (game console), "CD” (compact disk), and "Trojaner [Trojan horse]" (malicious software that masquerades as a message, file, or program). In the following, I analyze fragments of classroom and interview talk in terms of the changing nature of Swiss-German language over the past several decades. In fact, these terms and associated cultural life forms did not exist when the researcher collecting the data or I were of the age of the student participants in this research project.

A cultural-historical perspective of science- and technology-related language Although certain forms of information technology did not exist only a few decades ago, they now are so dominant in society that science and technology education researchers forget to generate theoretical model that describe and explain the changing nature of language rather than reasserts its stability as a communicative resource. Viewing language generally and words specifically as stable resources is the very reason we miss understanding language as a dynamic phenomenon (Romano 1998). Whereas some new words of a language may emerge in company and laboratory talk - e.g., names of new technologies - it is in the everyday vernacular that many associated forms of talk are produced and later enter formal language, as represented in dictionaries. Together with the changing language go changing relations to science and technology that characterize consecutive generations within a particular culture. The following fragment makes apparent that there are not only nouns denoting particular technologies but also a particular affective quality that characterizes this from preceding generations. Whereas the student participants were born into a world with PCs, cell phones, game consoles, laptops, mp3 players, and so on, these were developed by and "invaded" the worlds of preceding generations. Thus, it no longer surprises to hear that young people, 
male or female (here Marly), "thrive" on technologies such as cell phones ("Natel") and mp3 players. It appears as if almost everyone has a cell phone.

Fragment 6 ( $\mathrm{M}=$ Marly)

I> 84 R: Now a final question. When you look at your female and male colleagues, are you a more technology friendly generation or a technology skeptical generation?

A> 85 M: Technology friendly. Above all, what we have these days, we have everything, game consoles, PCs, laptops, Natels. I think that this has to do with technology, and we all thrive on it. Which young person, male or female, in our class does not have, for example, a Natel, perhaps one in twenty! It's just like that. Or an mp3 player and all that. I

Although no longer worth special note, a word such as "Natel" did not exist until about 40 years ago. The origin of the word Natel dates to the 1970s when the Swiss postal service introduced a mobile phone service operated in cars. Natel was an acronym for "Nationales Auto-TELefonnetz [National car telephone network]." After the dismantlement of the postal service, the newly founded Swisscom appropriated and registered the acronym, which became the name for cell (mobile) phones more generally; it became a generic concept used for all types of mobile phones. The term is not used in other German speaking countries, such as Germany or Austria, where the term "Handy" is more widespread. (Technically it is a "Helvetism," a characteristically Swiss-German word.) It appears, however, frequently in this database, as exemplified in Fragment 6.

The other German term for a cellphone, Handy, also has a cultural history. According to the dictionary of neologisms of the 1990s operated by the Institut für Deutsche Sprache [Institute for German Language] (IDS 2012), Handy is a possible derivation from the English lexeme handy, which was reinterpreted in German. It is a pseudo-Anglicism. This word entered the German language as a colloquialism and became more widely used in the 1990s. Its origin is not quite certain, but the term probably derives from the English adjective "hand-held (transceiver)," common among HAM operators (Pieper 2007). When the German Telekom introduced the first handheld devices to sell them to its customers in 1988, the word apparently emerged during an internal brainstorming meeting. From then on, company internal documents use the term Handy to refer to handheld telephones. From there, the word made it into the public and everyday language before being included in German-German dictionaries, and, subsequently, into dictionaries for other languages as "cell[ular] phone," "cell," "cellphone," "mobile phone," or "portable."

A frequent topic in classroom and interview talk with the Swiss students was SMS technology. SMS is new lexeme in German used either to denote a short message or a type of service (e.g., to send a message via SMS). As a service, it is a masculine noun, only used in singular, generally used without the definite article "der." The genitive form is SMS. In German, it is often used as the first part of a word that defines or determines the second part, as in SMS "SMS-Dienst [SMS service]" or "SMS-fähig [SMS capable]." It was introduced in the Duden, a reference spelling dictionary of the German language, in 2000, in the dictionary of foreign words of the 
same publisher in 2001, the same year that it also entered the universal dictionary (IDS 2012). As a message, it generally is a female noun and is used with the respective definitive article (i.e., die SMS); more rarely it is used in the neuter form (i.e., das SMS). That is, the sense of the word is a function of its gender, differentiated by the relevant in/definite article ("der" or "die" and "ein" or "eine"). In both genders, it has the same plural form (SMSen). It is used as a word stem (e.g., GratisSMS [free SMS message]) and as a determining word (e.g., SMS-Sucht [SMS addiction]"). Since about 2000, there is also a verb, simsen (also smsen, SMSen), which, according to the German hyphenation rules, can be broken at the end of a line into two: sim/sen (e.g., "Dem Freund die Neuigkeit simsen [To send the news by means of SMS]"). As a verb, there have to be conjugation rules: it is a weak verb (simsen, simste, gesimst). In the perfect tense, it takes the auxiliary verb haben [to have] (e.g., "Er hat gesimst [He has sent an SMS]"). It is also possible to form the passive. The IDS dictionary for neologism indicates possible syntactical environments (e.g., "jemand simst \{jemandem\} \{etwas\} [someone sends \{something by means of an SMS \{to someone\}], "jemand simst \{mit jemandem\} [somebody exchanges SMS \{with someone\}]"). The verb can also form new words such as ansimsen [to send an SMS to] or zurücksimsen [to return an SMS].

It is not just that new words enter a language individually and without repercussions for other parts of the language. New words are integrated grammatically. As terms are adopted from one language into another, they may change their gender, with important grammatical repercussions in languages where personal pronouns, for example, have to match the gender of the owner (e.g., English), object (French), or both (German). In German, there exist additional grammatical possibilities when nouns are combined with other nouns. As a basic word, Internet (neuter, singular, two genitive forms) can produce other new basic words (e.g., Kabelinternet [Internet via cable] or TV-Internet) and, as determining word, leads to a proliferation of new words some of which are combinations with traditional German words (Internetadresse, Internetauftritt [Internet appearance]) and others combined with other words from English written in Germanic form (e.g., Internetuser) or as combination of two noun forms (Internet-User), in any case, requiring rules of spelling and hyphenation (e.g., In/ter/net/user), which tend to differ from the English forms (us|er).

New forms of action and changing social relations Associated with new forms of technology are new ways of relating to and affecting (operating upon) others and the world. These new forms of relations are expressed by means of verbs. New verbs coincide with the expansion of agency, room to maneuver, and control over conditions. They also can be used to perform gender differences in new ways. In Fragment 7, the verb gamen, a derivative of the English noun "game" and verb "to game," is employed not only to describe a particular form of action but also to constitute a difference between male and female students, the latter not deploying the respective action as frequently as their male counterparts. That is, the verb gamen is part of a language game that constitutes the very differences that gender ideology is about and, in so doing, keeps gender differences alive (i.e., those very differences that the curriculum was designed to overcome). That is, in this example 


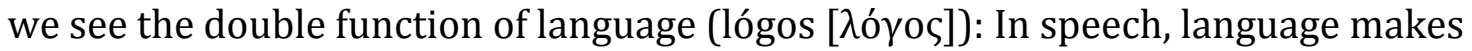
that stand out for the other participant/s in a situation of which it speaks about in speech (Heidegger 1977). In the present fragment, we actually observe one of the few exceptions, always possible within the present framework, where the positions are changed and the student produces a statement that offers up a question (turn 63a), which is accepted as such in the production of a response (turn 64).

Fragment 7 (Mario)

I> 60 R: What would you say, what do boys like? What does it have to be to go down well with boys?

A> $61 \mathrm{M}$ : Perhaps a bit more, well, more gadgets, from everyday, what you need, Bluetooth like that, radiation, today you have cell phones [Handys] like that. And what else you need.

I> 62 R: And with girls? Would it be different?

A> 63 M: I don't know. Yea, boys need more consoles like that, and they also have different things that interest them. And girls, they don't game that much [gamen nicht so]. Perhaps P-C.

I> a What are they interested in?

A> 64 R: I took something specifically from medicine, because I thought, perhaps it would interest girls and boys ....

I have not found the verb gamen [to play] in any of the dictionaries. It still is a word in statu nascendi (in the state of being born) at the collective level. But, being articulated, heard, and remaining unproblematical in and from the perspective of the conversation it is accepted of describing what boys do more than girls. But this does not mean that girls are not interested in or use technology. They do use, as apparent in turn 90 from the interview with Alicia, certain forms of technologies to act, including cell phones to send SMS messages and talk.

\section{Fragment 8 (Alicia)}

90 I: Basically, we agree. Moped engines are not really interesting to a girl.

91 A: Like cell phone [Handy], girls are interested in SMS and phoning.

92 I: Like communication, you could say?

93 A: Yea.

Other interviews confirm the possibility and intelligibility of non-gendered relations with and to technology:

Fragment 9 (Vanessa)

$49 \mathrm{~V}$ : I think we certainly know more about technology than our parents, in part. ... I would say, [we are] more technology friendly, especially more than the generation of our grandparents, this is for certain, because I see sometimes, how little they can do.

50 R: Well, between "can do" and "appreciate" there still is a difference 
Unlike the technical terms, such as Natel, mp3, or SMS, which tend to arise in the context of company speak, many verbs that come to change the Swiss-German language (as any other language) may actually be produced in a variety of different settings, including schools or the everyday out-of-school settings of students. However, even if this verb or another other word, like "to s(i)ms [simsen]" were to be spontaneously produced for a first time, its very production as a word presupposes its intelligibility, and, therefore, that the production precisely is not the origin of the word and the "first" speaker using it not its inventor. This is also evident in my own experience of living in a multilingual family. In our working language English, we used and experienced the emergence of the verb "to google" (/'gu:gl/) as referred to in the introduction. In its Germanized form "googeln," it is also a way of expressing the action of doing an Internet search in German. It is pronounced, however, inconsistent with the German pronunciation rules as /'gu:g(e)ln/ rather than /'go:geln/. That is, this new word has changed the German language more significantly and drastically: the very relation between phonetics and written form has changed with the introduction of the technology and its uptake in the German culture. Similar observations can be made in French. As my wife and I also speak French at home, we have used a French version "googler" (pronounced /'gu:gle/) even prior to hearing it used in conversations outside our family. The verb does not yet exist in formal French, as per uptake into the language-defining dictionary Le Grand Robert, but it has appeared in the English-French dictionary Termium operated by the Canadian government (www.termium.gc.ca). Again, the pronunciation follows the English and, therefore, changes the relation between phonetics and written forms of the French language. There is a dialectic process at work such that the first verbal articulation follows the (potential) intelligibility of a word. Thus, the (Swiss) language is not just a stable resource but itself an evolutionary project, continuously evolving in the course of speaking, itself a way of producing, reproducing, and transforming relations.

New verbs also may characterize forms of actions no longer related to the technology with which they have arisen. In Fragment 10, Marly produces the soundword "zugetextet" in a statement that opposes sitting for four hours (in a lecturetype lesson) versus participating in the present science-technology unit that "was more fun to participate [in]" (turn 03).

\section{Fragment 10 (Marly)}

02 R: Did you feel that this [unit on technology] was accepted by the class, was it a good thing, like on average?

$03 \mathrm{M}$ : Yea, for sure. I think above all it was just like that [es war locker], it was more fun to participate that when you sit there for four hours and are texted to [zugetextet], here we were able to do something on our own.

$04 \mathrm{R}$ : So these are things that really went down well with you?

The verb, having emerged in the late 1990s and early 2000s, is vernacular and generally is used in oral rather than written communication (OWID 2012). It can be heard as being on the receiving end of (SMS) text messages (based on the sense of $z u$ - as "to") and being covered (sense of $z u$ - as covering, filling). As the 
corresponding turn pair shows, the take up concerns something that went down well, that is, the more positive affective quality of participation that the technology unit offered.

Cross-language influences The analysis of any language shows that words from one language have been introduced to and adopted by other languages. For example, German includes many words of non-Germanic, Latin origin, which may have come, for example, from Italian or French. There are considerable numbers of German verbs based on a French root and a change of ending from -er or -ir to -ieren: marcher $\rightarrow$ march/ieren [to march], établir $\rightarrow$ etabl/ieren [to establish], or formuler $\rightarrow$ formul/ieren [to formulate]. Since the 1960s, this trend has increased as a consequence of increasing globalization of economy and culture: With the beat generation and the prevalence of music from Anglo-Saxon countries, a lot of English words have been taken up in Swiss German, as in other non-English European languages. For example, the teacher and researcher used the word sexy. The English adjective "sexy" became, in its original English form, a way of modifying German nouns in the 1990s. That is, in the interviews there are statements such as "das wäre jetzt nicht gerade ein sexy Thema [this would not really be a sexy topic" or "Warum ist das so unsexy [Why is this [technology] not so sexy]?" would not have been heard or seen before the mid-1990s. But, as the following fragment shows, it is used and apparently understood by both interlocutors (because taken as unproblematic in the conversation).

\section{Fragment 11 (Vanessa)}

$91 \mathrm{~V}$ : How a refrigerator is constructed, I would not necessarily take it [as a topic], it is somehow, I don't know.

I> 92 R: Why is it so unsexy?

A> $93 \mathrm{~V}$ : I don't know, because you need it every day or because there is nothing mysterious in it. For example, this fiber optics cable, there was something mysterious about it, and that, I don't know whether it was only me who was inspired by it, but I think, others also found it pretty cool.

Here, Vanessa articulates the structure of a refrigerator and how it is something that she would not take as a topic for technology lessons (turn 91). As the uptake shows (turn 92), the statement is heard as expressing a negative affective tonality: the construction of a refrigerator is "unsexy." The statement is offered and taken up as a question, as the second member of the pair constitutes a response where unsexy comes to be paired with the everyday, mundane nature of the refrigerator contrasted with the mysterious nature of fiber optics. In its uptake in (Swiss) German, the adjective sexy recognizably retains its original pronunciation, but its opposite may change phonetically from the English / $\Lambda$ 'seksi/ to /'rnseksi/. Whereas in English, the word cannot be hyphenated, it can be hyphenated in German (se|xy). Grammatically, it cannot be declined (inflected) invariably modifies its noun in the different cases. 
Other instances of uptakes from the English present in the present classroom and interview talk include combinations of the amplifying prefix "mega" with a range of words: mega-wichtig [mega important] or mega-Hirnakrobatik [mega brain acrobatics]. Words such as freak and fan are combined with the German word Technik [technology, engineering] to form neologisms such as Technikfreak [technology freak] or Technikfan [technology aficionado]. And, as such, they may again be used to constitute gender differences and gender involvement, attributing such forms of engagement more to boys than to girls. For some of these uptakes there are German alternatives, but these may not be used in concrete speech situations and, therefore, do not ultimately survive. For example, in the present data corpus, participants take about and make reference to Bluetooth data-transmission technology. It derives its name from and constitutes homage to the very communicative Viking king Harald Blåtand, whose nickname was Bluetooth or, in German, Blauzahn. Although the term Blauzahn is possible and legitimate, it is used only infrequently. The English Bluetooth (neuter, mostly without article, genitive: bluetooth; German spellings also: Blue Tooth, bluetooth; blue|tooth; Blauzahn).

Experiencing science and technology New forms of language change what can be made to stand out in experiencing science and technology. In the following interview fragment with Philipp, a student more interested in technology than in other school subjects, the historical changes become the topic of the conversation.

\section{Fragment 12}

78 R: Were you still there when I watched with the video camera?

79 P: Yea.

80 R: Then I had the sense that the skepticism towards technology did not exist. Did it?

81 P: Like what?

82 R: You know, our generation, when we were your age, found a lot of technology really dangerous or problematical.

83 P: Like, I think, nowadays technology becomes mundane. Yea. It is nothing dangerous, nothing special, simply-

84 R: How is it with things like genetic engineering [Gentechnik], for example, cloning, do you find this is something good or rather something bad?

It is therefore not merely an addition of one or more words to a language that need to be taken into account, but the very orientation toward technology may change with the change of language and the presence of technology in the life of a people. Whereas technological artifacts were frightening to the older generations in the population, they are no longer such among the youth of today. In fact, (fear of) technology becomes a way of constituting generational differences. As Philipp says, the presence of technology in everyday life makes technology mundane. It is nothing special and there is nothing particularly dangerous about it. Technology and the language that comes with it are part of the lifeworld that these students were born into and inhabit rather than changes that they were confronted with. The skepticism toward technology that might have existed in the post-WWII generations has 
lessened; and the change in technology-related grammatical and semantic forms is associated with different forms of experiences and accounts thereof.

\section{The hybrid nature of language, vernacular, and science and technology talk}

The purpose of this study is to develop a sociological perspective on language in science education. I present and develop the implications of a (Marxist) sociological position to language as a living phenomenon at the moment-to-moment, individualdevelopmental, and cultural-historical evolutionary levels. The position is exemplified with materials collected in the context of classroom and interview talk with 14-year-old Swiss-German non-academically streamed lower secondary students about technology and science. Following the hierarchical research approach that Vološinov (1930) framed, I first analyze the forms and types of verbal transactions in a given cultural field (here lesson and interviews on the topic of technology and science); secondly, I unpack the forms of statements and speech acts in relation to the social intercourse; and finally I examine recent changes in the Swiss-German language associated with a number of concept-words that appear in the recorded interview and classroom situations. That is, to understand (scienceand technology-related) language-in-use, a three-leveled analysis is necessary.

It is apparent from the data mobilized here that the mundane language penetrates the more academic settings of schooling and interviews, which involved a person from the university who had taught the lessons, but who also wanted students to feel at ease. In fact, the basis of the change of language is the vernacular, which constitutes the foundation of all language and the way in which we navigate in and around the world; and this vernacular is integral to the lifeworld we inhabit. From a pragmatic perspective, it is impossible to distinguish knowing a language and knowing one's way around the world more generally (Rorty 1989). Texts whether these are produced through talking or writing - and their contexts are indissociably and irreducibly intertwined (Roth 2010). In producing texts, we always already produce contexts (i.e., social/societal relations). Thus, the students, teachers, and researcher in this study do not merely talk content; in and with talking content they produce the very situation that is the context of their talk: the lessons and interviews. Every word is directed not only to talk content but also to the business of making the situation what it is - i.e., a science and technology lesson, an interview about science and technology topics. And in the very use of language, it is changed.

There are members in the field of science- and technology-related education who are disinterested in more general aspects of the culture - relations, language and linguistics, transactional patterns - and exclusively focus on "conceptions," "beliefs," or "interests." In this paper, I suggest that without the soci(et)al relation, no talk about science- and technology-related "conceptions," "beliefs," or "interests" are possible. Saying that one is interested in these phenomena alone irrespective of the situation that enables them is like requesting the removal of all the walls of a house to see its inside. It may just be that inequities with respect to science and 
technology are produced in and as these relations rather than by means of any other aspect of science lessons.

In this study, the unit of analysis is the turn pair. Inherently, a turn pair manifests itself in the contributions of two speakers. However, the turn pair cannot be reduced to one or the other person because in addressing the second speaker, the language of the first already includes moments of the second; and, because it directly addresses and takes up the first turn, the language of the second turn is irreducibly characterized by the first turn. Moreover, the turn sequences and the transaction rituals that they realize are specific to the societal "institution" that is produced while talking and talking about the pertinent issues. Thus, the turn taking ritual differs when we compare interviews with classroom talk. The contexts are very different societal activities and, from a cultural-historical activity theory perspective, involve very different object/motives, divisions of labor, or rules requiring and realizing very different forms of transaction rituals. Therefore, what an analysis such as that presented here yields are not opinions, beliefs, interests, values, or knowledge of individuals. Rather, the analysis focuses on language-in-use and, with it, the system of ideas - i.e., ideology - underlying, embedded in, and mobilized by it. The language in which all science classroom talk, as all science, technology, or engineering talk in the world, is grounded in the vernacular (Bakhtin 1990). This vernacular is tied up with the lifeworld as we inhabit and experience it (Husserl 2008). It constitutes the foundation of everything we know and do so that there is no difference between knowing the vernacular and knowing our way around the world more generally.

In the current literature, a language generally and a scientific discourse specifically tend to be treated as a stable entity with particular structures and semantic patterns, which we learn from others "by speaking it with those who have already mastered it" (Lemke 1990, p. 1). In the approach presented here, changes in language occur in living speech activity, itself subordinated to the current activity and its particular orientations (schooling, research interviewing). That is, rather than thinking about the appropriation of particular structures and semantic patterns, the present approach highlights the novel production and change of language on the part of learners. That is, learners are integral to the changing nature of language. The language of everyday life is the vernacular. Across his work, Bakhtin shows that it is only when we consider the vernacular as living and constantly changing that we may understand such developments as the changes in literary genres through the history of literature. But we cannot understand the changes within and between genres if we just look at the genres themselves, lining them up in a historical sequence trying to understand the logic of how the novel of one period is connected to the novel of another period. This vernacular itself is heterogeneous, a hybrid. Thus, when students come to the science classroom, they bring with them considerable fluency in the vernacular - in the case of the present study Swiss German. This vernacular constitutes the ground, tool, and object in their endeavors of engaging with science topics. We therefore would anticipate that rather than creating some third space, coming into existence in the conjunction of the vernacular and science language, one instead will observe the continued hybridization of the vernacular. Because the vernacular changes, both across 
historical and individual time scales, it is never the same. The approach presented here takes this into account, because any turn is part of a collectively produced turn and, therefore, inherently different for speaker and recipient, and inherently spread out across time. One cannot say, however, that this perspective does not represent the actors' view of view. By situating itself at the level of the turn pair, which reveals how a turn contributes to constituting the next in a sequence of turn, the viewpoint is very much that of the actors (Rawls, in Garfinkel 2002). Yet because the phenomena described are irreducibly social events, the view is no longer that of the individual but one representative of culture and society. It presents what happens from the level of the shop floor, here classroom or interview, where the social relation is produced and maintained.

The Marxist sociological approach has tremendous implications for and applications in science curriculum. One area of application is the work on "misconceptions," "alternative conceptions," or "naïve frameworks." If the vernacular language and the lifeworlds made thematic in and with it do in fact constitute ground, tool, and topic of (classroom) talk, then this dispels any hope of eradicating misconceptions or naïve ideas. These have lives of their own in vernacular and are re/produced and transformed together with it. Eradicating, removing, and overcoming misconceptions and naïve ideas would be equivalent to eradicating, removing, or overcoming the vernacular - a quixotic endeavor indeed. Instead of trying to eradicate, remove, or overcome the vernacular and its ideas (e.g., Barke et al. 2009), science educators might actively embrace it. More so, they might embrace it because the speech activity in science classrooms itself provides opportunities to language for transforming itself through new creations and hybridizations. However, rather than trying to reproduce the language of the canon - in the way members of some religions and religious sects do - tying science talk to technologies of interest to students offers opportunities for bringing about change in the talk not only at the classroom level but also in the society at large. The focus of science education cannot be individual students unless they and their language capacities are considered in the dialectical relation to society. When the possibilities for talking science and technology change at the societal level, they do so at the individual level; but for the changes to occur at the societal level, they have to be produced at the individual level. Little appears to happen currently to enable broader changes in science- and technology-related language, which, I believe, would more likely happen if the students were truly and more involved in the selection of curricular topics and the design of curriculum. In this way, the fervently productive nature of vernacular would be used actively in the science curriculum with repercussions in the extended conversations that the students do in any event have with members of their family and in the circles of their friends.

\section{Coda}

Here at and as the end, I return to and emphasize two issues that have come up recurrently in conversations with colleagues and reviewers: (a) the relation between the individual speaker and language as a collective phenomenon and (b) 
the methodological issue research is confronted that focuses, as this study does, on the way in which social/societal situations are produced from the inside (i.e., endogenously).

First, a friend and colleague, after reading an early draft of this paper, commented in this way: "When I read your text, it appears that the specific people and their comments do not interest you. They are sources of text ... and they have no independent existence. I have the sense that these could be any students, any interviewer, and any topic." I wrote to the friend saying that this is precisely my point. Rather than taking it as a critique, I consider the comment to be a compliment, for the text has precisely achieved what it sets out to achieve: a sociological perspective on language-in-use and the irreducibility of soci(et)al phenomena that are independent of the particular individuals who staff them. If the account of language concerning science and technology is independent of the particular individuals, then it is a reflection of the culture and language of the particular society where this talk was recorded. Moreover, we say and understand generalities despite human individuality. That is, our own singularity, experienced day in and day out, is an effect of human society, societal relations, and language (Vygotskij 2005). This is the central point of the classical framing of cultural-historical approach: "the psychological nature of man - a set of societal relations, shifted to the inner of man and having become functions of the personality and its structures" (p. 1023 , original emphasis). In the present text, the analysis focuses on the societal relations that at other times are attributed to individuals. But this ascription presupposes the societal relations, for otherwise, there would be no "psychological nature of man." Vygotsky drives this point home: "If relationships among people genetically underlie psychological functions, then: (1) it is ridiculous to look for specific centers of higher psychological functions or supreme functions in the cortex" (p. 1023). Instead, I propose in this article to analyze societal relations and (inherently collective) language (it speaks, as Heidegger says in the introductory quotation); and, in this move, the specific individuals, teachers or students, are no longer of interest. That is, the analyses provided here provide us with a microcosm of Swiss society rather than with the views of particular students attending a particular school in the Canton of Zurich, Switzerland.

Second, preliminary versions of this text have drawn comments about the need to add a methods section, to provide assurances to guarantee reliability and trustworthiness of my interpretations. But the approach chosen here is very different. When Zeyer taught and debriefed the course, he did not know or have background information on the students; and the students did not know or have background information on Zeyer. The same is the case for the interview situations involving the interviewer (Zeyer) and the students. And yet: in and through their talk, they pulled off the lessons, the whole-class debriefing, and the interviews. They did so simply based on the resources that they made available to each other in the talk. They organized the entire lessons, whole-class debriefings, and interviews from the inside, endogenously (e.g., Garfinkel 2002), so to speak. To understand how they pulled off these feats, we therefore must not look elsewhere, for other information. Rather, we must look at the societal relations themselves and the talk that occurred within (plus gestures, body orientations, body movements, prosody, etc.). What are 
the resources that participants produced to make this endogenous production possible? Moreover, this approach does not require competencies in special (research) methods but precisely in the same (everyday, mundane) methods that allowed Zeyer and the students to pull off these feats. The quality of the analysis, its trustworthiness, must therefore be grounded in precisely those resources and competencies that the participants in the settings not only drew on but made available and therefore accountable to each other in the course of their talk.

\section{Acknowledgments}

I am grateful to Albert Zeyer (who conducted the whole class discussions and individual interviews) for providing me access to the classroom video and interview recordings and to the transcriptions in High German. The translations from High German into English are mine. I thank him for his comments on an early version of this manuscript. All statements of facts and all opinions are mine.

\section{References}

Bakhtin, M. M. (1975). Voprosy literatury i estetiki [Problems in literature and aesthetics]. Moscow, Russia: Xudoš. Lit. (English: The dialogic imagination, Austin, TX: University of Texas 1981.)

Bakhtin, M. M. (1979). Estetika slovesnogo tvorčestva [Aesthetics of verbal creation]. Moscow, Russia: Iskusstvo. (French: Esthétique de la création verbale, Éditions Gallimard, Paris, France 1984)

Bakhtin, M. M. (1990). Tvorčestvo Fransua Rable i narodnaja kul'tura srednevekov'ja i Renessansia [The work of François Rabelais and popular culture of the Middle Age and Renaissance. Moscow, Russia: Xudošestvennaja literatura. (Assistance from the French translation L'œuvre de François Rabelais et la culture au Moyen Age et sous la Renaissance, Paris, France: Gallimard, 1970) (First published in 1965)

Bakhtin, M. M. (1994). Problemy poètiki tvorčestvogo Dostoevskogo [Problems of the poetics in the work of Dostoevsky]. Kiev, Russia: Next. (Parts reproduced in the English: Problems of Dostoevsky's poetics, Minneapolis, MI, University of Minneapolis Press 1984) (First published in 1929)

Barke, H.-D., Hazari, A., \& Yitbarke, S. (2009). Misconceptions in chemistry: Addressing perceptions in chemical education. Dordrecht, The Netherlands: Springer.

Benenson, G. (2001). The unrealized potential of everyday technology as a context for learning. Journal of Research in Science Teaching, 38, 730-745.

Canada, K., \& Brusca, F. (1992). The technological gender gap: Evidence and recommendations for educators and computer-based instruction designers. Educational Technology Research \& Development, 39 (2), 43-51.

Derrida, J. (1996). Le monolinguisme de l'autre ou la prothèse d'origine [Monolingualism of the Other; or, The prosthesis of origin]. Paris, France: Galilée.

Dewey, J. (2008). Experience and education. In The later works vol. 13 (pp. 5-62).

Carbondale, IL: Southern Illinois University Press. (First published in 1938) 
Dewey, J., \& Bentley, A. F. (2008). Knowing and the known. In J. Dewey, The later works vol. 16 (pp. 1-294). Carbondale, IL: Southern Illinois University Press.

Eidgenössische Technische Hochschule Zürich. (ETH). (2012). Technik in der Allgemeinbildung [Technology in general education]. Accessed August 262012 at www.educ.ethz.ch/unt/um/ta.

Garfinkel, H. (2002). Ethnomethodology's program: Working out Durkheim's aphorism. Lanham, MD: Rowman \& Littlefield.

Gee, J. P. (1990). Social linguistics and literacies: Ideology in discourses. London, UK: Falmer Press.

Heidegger, M. (1977). Sein und Zeit [Being and time]. Tübingen, Germany: Max Niemeyer.

Heidegger, M. (1985). Gesamtausgabe. I. Abteilung: Veröffentlichte Schriften 1910-1976 Band 12: Unterwegs zur Sprache [Complete works. I. Division: Published writings 1910-1976 vol. 12: On the way to language]. Frankfurt/M, Germany: Vittorio Klostermann.

Husserl, E. (2008). Husserliana Band XXXIX: Die Lebenswelt. Auslegungen der Vorgegebenen Welt und ihrer Konstitution. Texte aus dem Nachlass (1916-1937) [Husserliana vol. 39: The lifeworld. Interpretations of the given world and its constitution. Texts from the estate, 1916-1937]. Dordrecht, The Netherlands: Springer.

Hwang, S., \& Roth, W.-M. (2004). Co-evolving with material artifacts: Learning science through technological design. Journal of the Korean Association for Research in Science Education, 24, 76-89.

Institut der Deutschen Sprache. (IDS). (2012). Neologismenwörterbuch [Dictionary of neologisms]. Accessed July 92012 at www.owid.de/.

Lemke, J. L. (1990). Talking science: Language, learning and values. Norwood, NJ: Ablex.

Leont'ev, A. A. (1969). Jazyk, rec', recevaja dejatel'nost' [Language, speech, speech activity]. Moscow, Russia: Prosveščenje. (German: Sprache, Sprechen, Sprechtätigkeit, C. Heeschen, Trans., Stuttgart, Germany: Kohlhammer 1971.)

Leont'ev, A. N. (1983). Dejatel'nost'. Soznanie. Ličnost'. [Activity, consciousness, personality]. In Izbrannye psixhologičeskie proizvedenija vol. 2 (pp. 94-231). Moscow, Russia: Pedagogika. (German: Tätigkeit, Bewusstsein, Persönlichkeit, Cologne, Germany, PahlRugenstein 1982)

Mishler, E. G. (1991). Research interviewing: Context and narrative. Cambridge, MA: Harvard University Press.

Moje, E. B., Ciechanowski, K. M., Kramer, K., Ellis, L., Carrillo, R., \& Collazo, T. (2004). Working toward third space in content area literacy: An examination of everyday funds of knowledge and Discourse. Reading Research Quarterly, 39, 38-70.

National Research Council. (NRC). (1996). National science education standards. Washington, DC: National Academy of Sciences.

National Research Council. (NRC). (2012). A framework for K-12 science education: Practices, crosscutting concepts, and core ideas. Washington, DC: National Academy of Sciences.

Pedretti, E., \& Nazir, J. (2011). Currents in STSE education: Mapping a complex field, 40 years on. Science Education, 95, 601-626.

Pieper, D. (2007, June 29). Ein Wort und seine Geschichte: Woher kommt das Handy? [A word and its history: From where comes the handy?]. Spiegel Online Kultur. Accessed July 9 2012, at http://www.spiegel.de/kultur/gesellschaft/ein-wort-und-seinegeschichte-woher-kommt-das-handy-a-491413.html

Ricœur, P. (2010). Écrits et conférences 2: Herméneutique [Writings and presentations 2: Hermeneutics]. Paris, France: Éditions du Seuil. 
Ring, S. (2008, May 19). Tech gURLS: Closing the Technological Gender Gap. Edutopia. Retrieved August 26, 2012, from http://www.edutopia.org/computer-sciencetechnology-gender-gap

Romano, C. (1998). L'événement et le monde [The event and the world]. Paris, France: Presses Universitaires de France.

Rorty, R. (1989). Contingency, irony, solidarity. Cambridge, UK: Cambridge University Press.

Rose, S. L., \& Barton, A. C. (2012). Should great lake city build a new power plant? How youth navigate socioscientific issues. Journal of Research in Science Teaching, 49, 541567.

Roth, W.-M. (2001). Learning science through technological design. Journal of Research in Science Teaching, 38, 768-790.

Roth, W.-M. (2005). Doing qualitative research: Praxis of method. Rotterdam, The Netherlands: Sense Publishers.

Roth, W.-M. (2007). Toward a dialectical notion and praxis of scientific literacy. Journal of Curriculum Studies, 39, 377-398.

Roth, W.-M. (2008a). Bricolage, métissage, hybridity, heterogeneity, diaspora: Concepts for thinking science education in the 21st century. Cultural Studies in Science Education, 3, 891-916.

Roth, W.-M. (2008b). The nature of scientific conceptions: A discursive psychological perspective. Educational Research Review, 3, 30-50.

Roth, W.-M. (2010). Language, learning, context: Talking the talk. London, UK: Routledge.

Roth, W.-M. (2012). Tracking the origins of signs in mathematical activity: A material phenomenological approach. In M. Bockarova, M. Danesi, \& R. Núñez (Eds.), Cognitive science and interdisciplinary approaches to mathematical cognition (pp. 182-215). Munich, Germany: LINCOM EUROPA.

Roth, W.-M., \& Middleton, D. (2006). The making of asymmetries of knowing, identity, and accountability in the sequential organization of graph interpretation. Cultural Studies of Science Education, 1, 11-81.

van Eijck, M., \& Roth, W.-M. (2011). Cultural diversity in science education through novelization: Against the epicization of science and cultural centralization. Journal of Research in Science Teaching, 48, 824-847.

Vološinov, V. N. (1930). Marksizm i folosofija jazyka : osnovye problemy sociologičeskogo metoda b nauke o jazyke [Marxism and the philosophy of language : Main problems of the sociological method in linguistics]. Leningrad, USSR : Priboj. (French: Bakhtine, M. [Volochinov, V. N.] (1977). Le marxisme et la philosophie du langage: Essai d'application de la méthode sociologique en linguistique. Paris, France: Les Éditions de Minuit.)

Vygotskij, L. S. 2005. Psyxhologija razvitija čeloveka [Psychology of human development]. Moscow, Russia: Eksmo. (Quotations from chapter 7, "Thinking and Speaking," have been checked against the German: Denken und Sprechen 2002, Weinheim, Germany, Beltz)

Vygotsky, L. S. (1978). Mind in society: The development of higher psychological processes. Cambridge, MA: Harvard University Press. 


\begin{tabular}{|c|c|c|}
\hline $\begin{array}{l}\text { Time } \\
\text { (min) }\end{array}$ & Lesson plan & Materials \\
\hline 20 & $\begin{array}{l}\text { - Place X-ray images that students brought from home on } \\
\text { the overhead } \\
\text { - Students tell their story related to the image } \\
\text { - Look at the X-ray image, which bones can be recognized } \\
\text { and attributed to the human skeleton }\end{array}$ & $\begin{array}{l}\text { X-ray images } \\
\text { Overhead } \\
\text { projector }\end{array}$ \\
\hline 5 & $\begin{array}{l}\text { - Students pose questions to the thematic of X-rays. The } \\
\text { questions are recorded on a flipchart or chalkboard. } \\
\text { Students are encouraged to ask "stupid" questions. } \\
\text { - How do X-rays work? } \\
\text { - How dangerous are X-rays? } \\
\text { - Why are they called X-rays (Röntgenstrahlen)? } \\
\text { - Why do we need X-rays? } \\
\text { - Any question that arises subsequently will be added to } \\
\text { the collection. } \\
\text { - How were fractures diagnosed prior to X-ray } \\
\text { - machines? } \\
\text { - When there is nothing to see, what other } \\
\text { - What are laser rays? } \\
\text { - Is light unhealthy? } \\
\text { - How is the X-ray image projected onto the screen? }\end{array}$ & \\
\hline 30 & - Student experiment: Refracted light turns into colors & $\begin{array}{l}\text { Experimental } \\
\text { materials } \\
\text { optics }\end{array}$ \\
\hline
\end{tabular}

Fig. 1. Introduction to the thematic of X-rays (Lesson 1) 


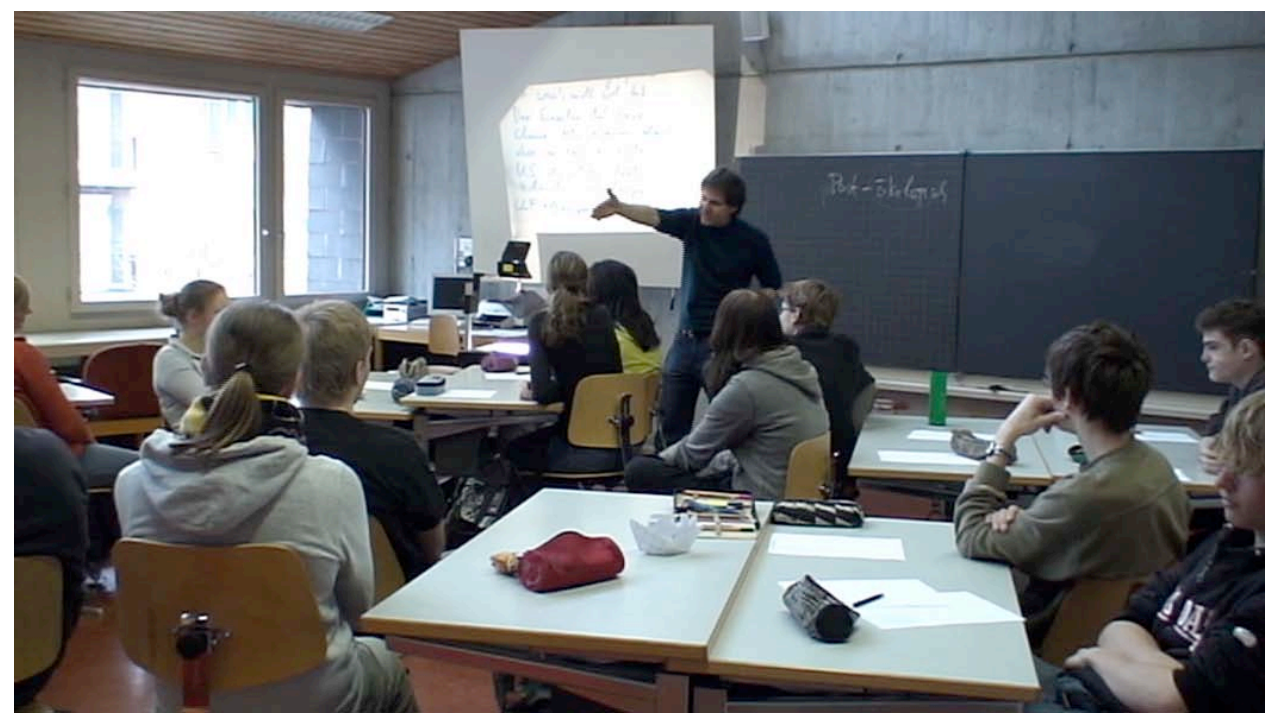

Fig. 2. Social situations configure, and are configured by, specific social relations, themselves subtended by typical speech genres. 


\begin{abstract}
Bio
Wolff-Michael Roth is Lansdowne Professor of applied cognitive science at the University of Victoria. His research concerns the learning of science and mathematics across the life span. His most recent works include First person methods: For a rigorous approach to the study of lived experience (Sense Publishers, 2012), Passibility: At the limits of the constructivist metaphor (Springer, 2011), Geometry as objective science in elementary classrooms: Mathematics in the flesh (Routledge, 2011), and, with L. Radford, A culturalhistorical perspective on mathematics teaching and learning (Sense Publishers, 2011).
\end{abstract}

